University of San Diego

Digital USD

Spring 5-24-2015

\title{
The Suitability of Habitats and the Effects of Human Activities in Osupuko and Olepolos Wildlife Sanctuaries on Maasai Giraffes
}

Sydney P. Davis

University of San Diego

Follow this and additional works at: https://digital.sandiego.edu/honors_theses

Part of the Animal Studies Commons, Biodiversity Commons, Other Animal Sciences Commons, and the Zoology Commons

\section{Digital USD Citation}

Davis, Sydney P., "The Suitability of Habitats and the Effects of Human Activities in Osupuko and Olepolos Wildlife Sanctuaries on Maasai Giraffes" (2015). Undergraduate Honors Theses. 11.

https://digital.sandiego.edu/honors_theses/11

This Undergraduate Honors Thesis is brought to you for free and open access by the Theses and Dissertations at Digital USD. It has been accepted for inclusion in Undergraduate Honors Theses by an authorized administrator of Digital USD. For more information, please contact digital@sandiego.edu. 


\section{Introduction}

The Amboseli National Park in southwestern Kenya is heavily reliant on dispersal areas and wildlife corridors to uphold a high level of biodiversity. Many of these dispersal areas and corridors are found in group ranches; within the group ranches there are also wildlife sanctuaries that are a joint effort between landowners and the African Wildlife Foundation (Wahungu, 2009). Wildlife sanctuaries were established in these group ranches in order to maintain the dispersal areas for wildlife from Amboseli National Park. The park and the group ranches form the Amboseli ecosystem. Large herbivores and medium-to-large carnivores are typically passage species of this ecosystem (Beier \& Loe, 1992). Passage species, including elephant, buffalo, zebra, wildebeest and gazelle, move over $5000 \mathrm{~km}^{2}$ during the rains each year, then retreat to the permanent water sources of the Amboseli basin in the park (Western, 2000). For wildlife with large home ranges these dispersal areas are essential for their survival for the dispersal areas allow for wildlife to travel for resources, to meet mates, and to interchange genetic material (Okello \& Kioko, 2010; Beier \& Loe, 1992).

At the same time, humans live within these sanctuaries and are allowed to conduct some human activities on the land. The main human activities within the sanctuaries include agriculture and pastoralism. The expansion of agriculture is one of the most serious threats to wildlife dispersal areas in the group ranches due to the clearing of rangelands, which destroys habitat resources (Okello \& Kioko, 2010). Livestock does not permanently displace wildlife, but compatibility with wildlife conservation and sharing of habitat resources is dependent on how much of the resources are available and the competition strategies animals use to acquire all their needs (Okello \& Kioko, 2010). The evidence that livestock compete with wildlife has remains weak because limitation of resources is often difficult to demonstrate (Madhusudan, 2004). 
However, wildlife populations have been negatively affected by and inversely related to livestock numbers (Prins, 2000). Giraffes are one of the many wildlife species that utilize these wildlife sanctuaries and they can be impacted by the detrimental effects on the surrounding vegetation, soil and resources due to deforestation, overgrazing by livestock and agro-chemicals.

The giraffe is the tallest land animal with an adapted neck that allows it to feed at heights that are unreachable to browsers who cannot climb trees (Estes, 1991; Fennessy, 2003). Giraffes are the ideal species for behavioral and social studies due to their large size and individually unique markings (Sinnary, 1998). Each giraffe has its own unique coat pattern, which allows for researchers to easily identify certain individuals. The Maasai giraffe (Giraffa camelopardalis tippelskirchi) also does not occur in large numbers like other ungulates such as zebra which makes is easier for researchers to record the specific patterns of giraffes and be able to identify them (Foster, 1966). The seasonal changes to the environment provide Maasai giraffes with different vegetation types, such as woodlands, bushlands, and riverines, that can be used to forage on different plant species.

It is necessary for giraffes to be able to travel to dispersal areas, such as wildlife sanctuaries, outside of Amboseli National Park in order to be able to find adequate resources to survive during the seasonal changes within the whole ecosystem. Incidentally, most giraffes don't leave Amboseli National Park, but extensively utilize the dispersal areas throughout the year; sometimes utilizing up to $168 \mathrm{~km}^{2}$. However, due to the increase in human activities within the wildlife sanctuaries, the habitats are being degraded. Human activities are negatively affecting the quantity of habitat resources available to giraffes through domestic use, agriculture and pastoralism. It will be determined in this paper whether the habitat degradation of different habitat types affect the number of giraffes that inhabit and utilize the habitat. It will also be 
determined if there is an adequate supply of food resources to sustain a viable giraffe population and if the presence of livestock within the dispersal areas affects giraffes.

\title{
Materials and Methods
}

\author{
Study Area
}

Two wildlife sanctuaries were considered for this study: Osupuko and Olepolos. Osupuko is $14 \mathrm{~km}^{2}$ in size and it is located near Kimana town in southwestern Kenya. It consists of mostly open Acacia mellifera bushland and Acacia tortilis woodland. There are also low hills, wet season drainage channels, flat plains, a spring and several hundred square meters of Lava rock outcrop with unique vegetation. Osupuko is classified as semi-arid to arid land with soils that are of volcanic origin, and mainly infertile except in a few areas of black cotton soil (Wahungu, 2011). Except for Isinet and Namelok springs, Osupuko does not have adequate water supply throughout the year. Olepolos wildlife sanctuary is slightly larger at $15 \mathrm{~km}^{2}$ with a more closed bushland habitat with occasional succulent Sansevieria spp. dominated habitats as well. The main human activity of the local people that reside in the sanctuaries is nomadic pastoralism with irrigated agriculture as a minor activity. The study was conducted during the long rain season in late April over a ten day span.

Both sanctuaries contain many wildlife species of such as African elephant (Loxodonta africana) Maasai Giraffe, Cape Buffalo (Cyncerus caffer), Warthog (Phacochoerus aethiopicus), Common Waterbuck (Kobus ellipsiprymnus), Grants gazelle (Gazella granti), Bushbuck (Tragelaphus scriptus), Eland (Taurotragus oryx), Kudu (Tragelaphus strepsiceros), Maasai Ostrich (Struthio camelus), Impala (Aepyceros melampus), and Burchell's zebra (Equus 
burchelli). Carnivores include lions (Panthera leo), leopards (Panthera pardus), cheetahs (Acinonyx jubatus), spotted hyenas (Crocuta crocuta) and jackals (Canis spp.) among others.

\section{Habitat Condition Assessment}

In each respective wildlife sanctuary, an assessment of the condition of the vegetation was conducted. The condition of a particular habitat was assessed on foot in transects of 1 kilometer in length. Based on the size of a particular sanctuary, it was necessary to conduct enough transects to cover at least $50 \%$ of the sanctuary's total area. Along each 1 kilometer transect there were five stops every 200 meters. The first sampling in each transect was started 200 meters from the starting point. Distances were measured using a GPS handset. At every stop the GPS coordinates were recorded, as well as the major habitat types and types of habitat degradation. There were four different types of habitat degradation including: vegetation damage, extent of invasion, bare ground cover and presence of overgrazed patches was evaluated using a scale of 1 to 5 . The scale is defined as: 1 : representing absence, 2: 1-25\%, 3:26-50\%, 4 : 51-75\%, and 5: 76-100\% presence of whichever type of degradation. Once a transect was completed, a succeeding start transect was laid 500 meters parallel to the previous transect.

\section{Animal Counts}

Animal counts were conducted within each quadrat in each sanctuary. Counts were performed along four 1 kilometer foot transects, stopping only if wildlife larger than a dikdik are spotted, including livestock. Livestock consisted of cattle and shoats (sheep and goat hybrids), which were recorded separately. The animal species were identified and counted as a total number and then separated into male, female and juvenile. The habitat type where the animal 
was located and the perpendicular sighting distance the animal species was away from the transect were also recorded.

\section{Determination of Woody Species Composition and Density}

The Point-Centered Quarter (PCQ) method and the quadrat method were used to obtain woody plant measurements. Sampling estimates were taken at $100 \mathrm{~m}$ intervals along randomly selected 1 kilometer transects. The four quarters at each sampling point were obtained using a compass in place of a cross frame. At each sampling point four quarters were separated from the center by walking 20 meters in the north, south, east and west directions, which created a 40 meter by 40 meter plot. The woody plants must have occurred near the sampling point at each quarter and must have had a diameter at breast height ( $\mathrm{dbh}$ ) of at least $\geq 5 \mathrm{~cm}$ and a height of at least 1 meter and be no further than 20 meters away from the quarter point. Three transects were completed, parallel to each other with 500 meters separating each transect. For each woody plant, the following parameters were recorded: quarter number, plant species name, distance from quarter point to the center of the trunk, diameter at breast height (dbh), and percentage of canopy cover. The distance from the quarter point to the woody plant species was measured using a tape measure. The dbh was measured using a clear ruler at a height of 1.3 meters above the ground. Plants were identified using Maasai names and later translated into scientific names. 
To determine the quality of each habitat type found within both sanctuaries the information collected from habitat condition assessment was used. This information includes percentage of vegetation damage, bare ground cover, extent of invasion and presence of overgrazed patches. The data was sorted by habitat type and then the mean value of percentage of vegetation damage, bare ground cover, invasion and presence of overgrazed patches was calculated for each habitat type. The mean values were used to rank the habitat types from the highest to the lowest. The habitat types were ranked for each category of damage. For example, one habitat can be ranked highest in vegetation damage, but also be lowest in bare ground cover. After each habitat type was ranked, the number of Maasai giraffes seen in each habitat was recorded in order to establish if there is a correlation between the quality of each habitat type and the number of giraffes seen in each habitat type. If there was a correlation, then linear regression was conducted to determine the type of relationship.

\section{Statistical Analysis of Food Availability}

In order to determine the quantity of food available for giraffes within the two sanctuaries, the most common food resources in the diet of giraffes was determined. The information collected from the Point-Centered Quarter method was used to calculate the density of each plant species. First the overall density of all plants species was calculated using Equation \#1. Then the relative density of an individual species was calculated using Equation \#2 and Equation \#3 was used to calculate the density of each plant species that are common in a giraffe's diet using the relative density from Equation \#2. The relative amount of food available of that plant species was calculated by multiplying the density of each plant species by the areas of the two sanctuaries. It was determined from these calculations whether the amount of food available in the sanctuaries is enough to sustain a viable giraffe population.

$$
D=\frac{1}{\bar{d}^{2}}
$$




$$
\mathbf{D}=\text { Density of all species }
$$

Equation \#1 $\quad d^{2}={\text { (Mean point-to-plant distance })^{2}}^{2}$

Equation \#2

$$
R D_{s}=\frac{n_{s}}{N} \times 100
$$

$$
D_{s}=\frac{R D_{s}}{100} \times D
$$

$$
\begin{aligned}
& \mathbf{R D}_{\mathbf{s}}=\text { Relative Density } \\
& \mathbf{n}_{\mathbf{s}}=\text { \# individuals of a species } \\
& \mathbf{N}=\text { Total \# of individuals (all species) }
\end{aligned}
$$

$D_{\mathrm{s}}=$ Density of one species

$\mathbf{R D}_{\mathrm{s}}=$ Relative Density

$$
\text { D = Density (all species) }
$$

Presence of Livestock vs. Giraffes

In order to establish a correlation between the number of livestock and giraffes present in each habitat type, the number of livestock and giraffes seen in each habitat type was determined. A correlation test was conducted to determine whether there is a correlation between cattle and giraffes as well as shoats and giraffes.

\section{Results}

Quality Assessment of Habitat Type

The highest ranked habitat type for vegetation damage was bush grassland (3.00) and the lowest ranked habitat type was bare ground (1.00). The highest ranked habitat type for bare 
ground was bare ground (5.00) and the lowest ranked habitat type was open Balanites glabra bushland with Sansevieria spp. ground cover (2.00). The highest ranked habitat type for the extent of invasion was bush grassland (3.50) and the lowest ranked habitat type was bare ground (2.00) (Table 1). The highest ranked habitat type for presence of overgrazed patches was bare ground (5.00).

The different habitat types Maasai giraffes were observed in are given in Table 2. The data in the table is the combined animal count of both wildlife sanctuaries. The data was combined in order to have an overall assessment of where Maasai giraffes were observed in the two sanctuaries and because the data is also being compared to the combined data of Table 1 . Giraffes were observed in closed Acacia tortilis bushland (10 individuals) and closed bushland where dominance of a plant species could not be determined (12 individuals) (Table 2). Closed bushland ranked third highest for percent vegetation damage (2.60), fourth for presence of overgrazed patches (2.80), fifth highest for percent bare ground cover (2.90) (Table 1). The lowest ranked habitat type was closed Acacia tortilis and mellifera bushland (1.38) (Table 1).

\section{Food Resource Availability for Giraffes}

The major plants species in a giraffe's diet and the number of each species found in each wildlife sanctuary were given in Table 3. Overall, Olepolos wildlife sanctuary had the greater number of each plant species than Osupuko with the highest number of Acacia mellifera species. Based off the basic needs for a bull to survive, it was assessed whether the number of each plant species is adequate to sustain a viable giraffe population. The average extent of damage of each plant species common in a giraffe's diet is given in Table 4. Commiphora africana has the least average extent of damage (5.00\%), Grewia bicolor has the highest average extent of damage (52.00\%), while the Acacia spp. are in between the two (Table 4). 
Effects of the Presence of Livestock on Giraffes

Table 5 represents the number of giraffes, cattle and shoats seen in different habitat types in Osupuko wildlife sanctuary. Table 6 represents the number of giraffes, cattle and shoats observed in different habitat types in Olepolos wildlife sanctuary. The two sanctuaries were separated in order to determine correlations between the livestock and giraffes in the two different areas. Results from Spearman correlation tests comparing the number of giraffes and shoats in Osupuko wildlife sanctuary revealed that the correlation coefficient between the two populations was not significant $(\mathrm{r}=-0.816, \mathrm{P}$-value $=0.1 .84, \mathrm{~N}=4)$. For Olepolos wildlife sanctuary, the correlation coefficient between giraffes and shoats was not significant as well $(r=$ $-0.889, \mathrm{P}$-value $=0.111, \mathrm{~N}=4$ ). Results from Spearman correlation tests comparing the number of giraffes and cattle in Osupuko wildlife sanctuary revealed that the correlation coefficient between giraffes and cattle was not significant $(r=0.775$, $P$-value $=0.225, N=4)$. For the Olepolos wildlife sanctuary, correlation coefficient between giraffes and cattle was not significant as well $(r=0.949$, $\mathrm{P}$-value $=0.051, \mathrm{~N}=4)$. The data supports the null hypothesis for the correlation analysis, which is that there is no relationship between the number of livestock and the number of giraffes in different habitat type.

Table 1 Average score of each habitat type found in Osupuko and Olepolos sanctuaries for percent of vegetation damage, overgrazed patches, bare ground, and invasion

\begin{tabular}{lllll}
\hline Habitat Type & Average & Average & Average & Average \\
score for & score for & score for \\
Vegetation & Presence of & Bare Ground \\
Damage (1- & Overgrazed \\
5) & $\begin{array}{l}\text { Patches (1- } \\
\text { E) }\end{array}$ & & $\begin{array}{l}\text { Invasion } \\
(1-5)\end{array}$ \\
& & 5 ) & & \\
\hline Bare Ground & 1.00 & 5.00 & 5.00 & 2.00
\end{tabular}




\begin{tabular}{|c|c|c|c|c|}
\hline Bush Grassland & 3.00 & 2.50 & 3.50 & 3.50 \\
\hline $\begin{array}{l}\text { Closed Acacia mellifera } \\
\text { Bushland }\end{array}$ & 2.00 & 1.43 & 2.52 & 2.86 \\
\hline $\begin{array}{l}\text { Closed Acacia mellifera } \\
\text { Bushland (Sansevieria spp. } \\
\text { Ground Cover) }\end{array}$ & 2.00 & 2.00 & 2.50 & 2.50 \\
\hline Closed Bushland & 2.60 & 2.80 & 2.90 & 2.46 \\
\hline Closed Acacia tortilis Bushland & 2.25 & 1.37 & 2.38 & 2.50 \\
\hline Dwarf shrubland & 2.56 & 2.67 & 2.89 & 2.56 \\
\hline Farmland & 3.00 & 4.00 & 3.00 & 3.00 \\
\hline Invaded Grassland & 1.50 & 2.50 & 3.00 & 3.00 \\
\hline Open Acacia mellifera Bushland & 2.20 & 2.40 & 2.80 & 2.60 \\
\hline $\begin{array}{l}\text { Open Acacia mellifera Bushland } \\
\text { (Sansevieria spp. Ground Cover) }\end{array}$ & 2.20 & 2.20 & 2.80 & 2.40 \\
\hline $\begin{array}{l}\text { Open Acacia tortilis Bushland } \\
\text { (Sansevieria spp. Ground Cover) }\end{array}$ & 1.86 & 2.43 & 2.71 & 2.57 \\
\hline Open Bushland & 2.11 & 3.09 & 3.11 & 2.86 \\
\hline $\begin{array}{l}\text { Open Balanites glabra Bushland } \\
\text { (Sansevieria spp. Ground Cover) }\end{array}$ & 2.00 & 1.50 & 2.00 & 2.50 \\
\hline Open Grassland & 2.66 & 2.66 & 2.50 & 3.33 \\
\hline $\begin{array}{l}\text { Open Sansevieria spp. Succulent } \\
\text { Shrubland }\end{array}$ & 2.38 & 2.30 & 2.38 & 2.61 \\
\hline Shrubland & 2.46 & 2.53 & 2.38 & 3.00 \\
\hline
\end{tabular}

Table 2 Number of Maasai giraffes observed in different habitat types.

\begin{tabular}{ll}
\hline Habitat Type & $\begin{array}{l}\text { Number of } \\
\text { Maasai Giraffe } \\
\text { observed }\end{array}$ \\
\hline Closed Acacia tortilis & 10 \\
\hline
\end{tabular}




\begin{tabular}{l}
\hline $\begin{array}{l}\text { Bushland } \\
\text { Closed Bushland }\end{array}$ \\
\hline
\end{tabular}

Table 3 Plant species in a Maasai giraffe's diet and the amount of each in Osupuko and Olepolos wildlife sanctuaries.

\begin{tabular}{ll}
\hline Plant Species & $\begin{array}{l}\text { Number of } \\
\text { individuals in } \\
\text { Osupuko WS }\end{array}$ \\
\hline $\begin{array}{l}\text { Acacia } \\
\text { ancistroclada } \\
\text { Acacia mellifera }\end{array}$ & 4,639 \\
Acacia tortilis & 71,691 \\
$\begin{array}{l}\text { Commiphora } \\
\text { africana }\end{array}$ & 21,833 \\
$\begin{array}{l}\text { Grewia bicolor } \\
\text { Table 4 Average percent of Extent of Da }\end{array}$ & 1,054 \\
\hline Plant species & $\begin{array}{l}\text { Average Percent } \\
\text { of Extent of }\end{array}$ \\
& Damage \\
\hline $\begin{array}{l}\text { Acacia } \\
\text { ancistroclada } \\
\text { Acacia mellifera } \\
\text { Acacia tortilis }\end{array}$ & 36.14 \\
$\begin{array}{l}\text { Commiphora } \\
\text { africana }\end{array}$ & 21.33 \\
Grewia bicolor & 5.00 \\
\hline
\end{tabular}


Table 5 The number of cattle, shoats and giraffes observed in different habitat types in Osupuko wildlife sanctuary.

\begin{tabular}{lccc}
\hline Habitat type & Cattle & Giraffe & Shoats \\
\hline $\begin{array}{l}\text { Closed } \\
\text { Bushland }\end{array}$ & 159 & 8 & 35 \\
$\begin{array}{l}\text { Dwarf } \\
\text { Shrubland }\end{array}$ & 0 & 0 & 80 \\
$\begin{array}{l}\text { Open } \\
\text { Bushland }\end{array}$ & 50 & 0 & 80 \\
Shrubland & & 0 & 382 \\
& 75 & 0 & \\
\hline
\end{tabular}

Table 6 The number of cattle, shoats and giraffes observed in different habitat types in Olepolos wildlife sanctuary.

\begin{tabular}{llll}
\hline Habitat type & Cattle & Giraffe & Shoats \\
\hline Closed Bushland & 25 & 4 & 0 \\
Closed Acacia mellifera Bushland & 20 & 0 & 111 \\
Closed Acacia tortilis Bushland & 28 & 10 & 0 \\
Open Sansevieria spp. Succulent & 22 & 0 & 9 \\
Bushland & & & \\
\hline
\end{tabular}

\section{Discussion}

The Quality of Habitat Type and Quantity of Giraffes 
Based off the results and what was observed, the habitat types with the highest percent of vegetation damage were bush grassland and farmland. For farmland to be the highest ranked habitat makes sense due to farming activity being the primary purpose of that habitat. It has been observed that the development of agricultural clusters and the growth of towns and markets in the dispersal areas of Amboseli National Park has led to increased pollution, fragmentation of water system, erosion and degradation of vital habitats for wildlife (Okello \& D’Amour, 2008). Closed bushland was ranked third for vegetation damage, fifth for bare ground cover, and fourth for the presence of overgrazed patches. Closed Acacia tortilis bushland was also ranked seventh highest for percent of vegetation damage. Ten giraffes were seen in closed bushland and twelve giraffes were found in the closed Acacia tortilis bushland. One study had found that the biomass densities of mixed feeding species, like giraffes and Grant's gazelle, were significantly lower in Amboseli National Park due to the decline in woodland habitats (Worden et al., 2003).

However the same study found that giraffes are less vulnerable to habitat loss as well as land-use intensification for agriculture (Worden et al., 2003). So it may be the case that despite the high percentage of vegetation damage and decrease in quality of the closed bushland habitat, giraffes are more resilient than other species to major changes of their preferred habitat.

\section{Food Resource Availability for Giraffes}

The major tree species necessary for a habitat to be viable for giraffes are Acacia, Commiphora, and Grewia (Kingdon, 1997). Giraffes can eat from 34 to 75 kilograms of food per day. It is not surprising that Acacia mellifera is the most abundant in both wildlife sanctuaries because he Acacia spp. was the most common in the bushland habitat type. It is also not a surprise that Olepolos wildlife sanctuary overall has more abundance in numbers of each plant species than Osupuko wildlife sanctuary. There was more bushland habitat in Olepolos than 
Osupuko. However, despite the high abundance of Acacia spp. within both wildlife sanctuaries, they do not have the highest extent of damage.

Acacia mellifera was the most abundant plant species with an average percent of extent of damage of $15.93 \%$. This result does not corroborate the fact that Acacia mellifera is known to have wood that makes good fuel and excellent charcoal (Noad \& Birnie, 1989). Acacia ancistroclada had the highest extent damage of the Acacia species found within the two wildlife sanctuaries even though it is the least abundant of the Acacia spp. Interestingly, Grewia bicolor was the least abundant within both sanctuaries, but had the highest extent of damage. This finding can be due to the fact that children eat the sweet fruit and the leaves are browsed by domestic stock (Noad \& Birnie, 1989). Commiphora africana was the least abundant of all the plant species with the lowest extent of damage. Interestingly, the species is used for its various medicinal properties and to make natural fences around homes and farms (Noad \& Birnie, 1989). It could be possible that it is necessary for humans to uproot or cut the whole stem of the plant. Despite the extent of damage on the Acacia spp. within the two sanctuaries, it can be concluded that its abundance is a factor that draws giraffes to the closed bushland and closed acacia tortilis bushland. It can also be concluded that the high number of Acacia spp. can sustain the giraffe population.

Effects the Presence of Livestock have on Giraffes

Local people who live within both wildlife sanctuaries utilize the area for pasture of their livestock. The common types of livestock seen in the sanctuaries were shoats (goats and sheep hybrid) and cattle. The results reveal that cattle and shoats were seen in certain habitat types where giraffes were not seen: Closed Acacia mellifera Bushland, Dwarf Shrubland, Open Bushland, Open Sansevieria spp. Succulent Shrubland, and Shrubland. The habitat types both 
livestock and giraffes were seen in was the closed Acacia tortilis bushland and closed bushland. Giraffes are usually found in woodland and bushland habitat during the rainy season due to increase in deciduous foliage growth (Kingdon 1991; Estes, 1997). Past research has also noted that male and female giraffes have different vegetation type preferences (Young \& Isbell, 1991; Foster, 1966). Females with young prefer open vegetation types such as woodlands and open bushland. One study suggests that females with young may prefer more open habitats because those habitats provide better nutrition and they provide better views of predators (Pellew, 1984). Interestingly, there were no giraffes observed in open bushland habitat in either of the sanctuaries. The absence of giraffes in open bushland can be explained due to the presence of livestock as well as the open visibility provided in the habitat, which does not provide much cover.

However, the correlation between giraffes and livestock was not significant and therefore there was no cause and effect relationship between the two species. These results contradict with a study of the effects of cattle grazing on selected habitats of southern mule deer (Bowyer \& Bleich, 1984). The study found that there are low densities of southern mule deer on ranges where cattle were pastured in spring and summer and an abundance of deer on similar ranges without cattle, which suggests that cattle use of mountain meadows negatively affects deer numbers (Bowyer \& Bleich, 1984). It may also be the case that giraffes are not affected as much as other wildlife species when it comes to human activity and coexisting with livestock.

\section{Conclusion}

Even though the closed bushland habitat was one of the highest ranked habitat types in terms of the amount of vegetation damage, overgrazed patches and bare ground cover, giraffes were observed in the habitat. It could be that Maasai giraffes are less vulnerable to damage 
within habitats than other wildlife species. There is a high number of Acacia spp. within both sanctuaries with Olepolos wildlife sanctuary having a higher number than Osupuko wildlife sanctuary. Despite the small number of Commiphora spp. and Grewia spp., the high number of Acacia spp. allow for both sanctuaries to sustain a viable Maasai giraffe population with Olepolos wildlife sanctuary being better suited for giraffes. By comparing the number of cattle, shoats and giraffes observed in different habitat types within the two sanctuaries, it can be concluded that there is no relationship between the number of cattle and shoats and the number of Maasai giraffes. Therefore, the presence of livestock in different habitats types within these two sanctuaries does not affect the number of Maasai giraffes within the same habitat types.

\section{Limitations to the Study}

This study could be improved if there was more time to conduct field-work. Ten days in the field was not adequate to acquire dependable data for animal counts, plant-herbivore interactions and body condition score. Furthermore, having more days and different seasons to observe the wildlife species that inhabit the sanctuaries, how they utilize the plant species and their body conditions could increase the amount and variability of the data.

\section{Recommendations}

Despite the high resilience of Maasai giraffes against high amounts of habitat damage, it is recommended that measures be taken to prevent further habitat degradation. Manual uprooting of invasive species and prevention of repeated livestock grazing in the same areas of the sanctuary can help prevent and reduce damage to the habitats that Maasai giraffes utilize. Future research should determine if more giraffes inhabit Olepolos sanctuary than Osupuko due to either the large amount of food resources available, area of preferred habitat type available or 
the amount of water available. Another study can be conducted to determine the overall activity pattern and feeding ecology of giraffes in the Amboseli ecosystem. These two studies will aim to collect more information on the behavior of Maasai giraffes and to have a better understanding of how suitable the sanctuaries are to the Maasai giraffe population of the Amboseli ecosystem.

\section{Appendices}

Appendix 1 Spearman correlation coefficient analysis between the number of giraffes, shoats, and cattle in Osupuko Wildlife Sanctuary.

\begin{tabular}{|ll|l|l|}
\hline & & Cattle & Shoats \\
\hline Spearman rho Giraffes & $\begin{array}{l}\text { Correlation } \\
\text { Coefficient } \\
\text { Sig. (2-tailed) }\end{array}$ & 0.775 & -0.816 \\
$\mathrm{~N}$ & 0.225 & 0.184 \\
& 4 & 4 \\
\hline
\end{tabular}

Appendix 2 Spearman correlation coefficient analysis between the number of giraffes, shoats, and cattle in Olepolos Wildlife Sanctuary.

\begin{tabular}{|ll|l|l|}
\hline & & Cattle & Shoats \\
\hline Spearman rho Giraffes & $\begin{array}{l}\text { Correlation } \\
\text { Coefficient }\end{array}$ & 0.949 & -0.889 \\
& Sig. (2-tailed) & .051 & \\
$\mathrm{~N}$ & 4 & .111 \\
& & 4 \\
\hline
\end{tabular}




\section{Literature Cited}

BEIER, P. \& LOE, S. (1992). A Checklist for Evaluating impacts to Wildlife Movement

Corridors,. Wildl, Soc. Bull. 20: 434-440.

BOWYER , T. R. \& BLEICH, V. C. (1984). Effects of Cattle Grazing on Selected Habitats of Southern Mule Deer. Calif. Fish and Game. 70(4): 240-247.

ESTES, R.D. (1991) The Behavior Guide to African Mammals Including Hoofed Mammals, Carnivores, and Primates. University of California Press, Ltd. London, England.

FENNESSEY, J. Ecology of Desert-dwelling Giraffe Giraffa Camelopardalis. Thesis. N.p.: University of Sydney Australia.

FOSTER, J.B. (1966) "The Giraffe of Nairobi National Park: Home Range, Sex Ratios, The Herd, and Food." E. Afr. Wild J. 4: 139-48. Print.

KINGDON, J. (1997). The Kingdon Field Guide to African Mammals. Bloomsbury Publishing London, UK.

MADHUSUDAN, M. D. (2004). Recovery of wild large herbivores following livestock decline in a tropical Indian wildlife reserve. J. Appl. Ecol. 41: 858-869.

NOAD, T. C. \& BIRNIE, A. (1989). Trees of Kenya. Nairobi, Kenya. 
OKELLO, M. M. \& D’AMOUR, D. E. (2008). Agricultural expansion within Kimana electric fences and implications for natural resource conservation around Amboseli National Park, Kenya. J. Arid Envi. 72: 2179-2192.

OKELLO, M. M. \& KIOKO, J. M. (2010). Contraction of Wildlife Dispersal Areas in Olgulului-Ololorashi Group Ranch around Amboseli National Park, Kenya. Open Cons. Bio. J. 4: 34-45.

PRINS, H. H. T. (2000). Competition Between Wildlife and Livestock in Africa. Wildlife Conservation by Sustainable Use. Kluver Academic Publishers, Boston, MA.

PELLEW, R. A. (1984) The feeding ecology of a selective browser, the giraffe (Giraffa camelopardalis tippelskirchi). J. Zoo1. (Land.) 202: 57-81.

SINNARY, S. M. Behaviour and Population Dynamics of Maasai Giraffe (Giraffa Camelopardalis) on Kenyan Game Ranch. Thesis. University of Nairobi, 1998. Nairobi: University of Nairobi, 1998. Print.

WAHUNGU, G. M., 2011. Conservation Plan for Osupuko Community Conservancy, s.l.: Moi University.

WESTERN, D. (2000). Amboseli National Park: Enlisting Landowners to Conserve Migratory Wildlife, Ambio. 11: 302-308.

WORDEN, J., REID, R. \& GICHOHI, H., 2003. Land-Use Impacts on Large Wildlife and Livestock in the Swamps of the Greater Amboseli Ecosystem, Kajiado District, Kenya, Nairobi, Kenya: International Livestock Research Institute.

YOUNG, T.P. \& ISABELL, L.A. (1991) Sex Differences in Giraffe Feeding Ecology: Energetic 
and Social Constraints. Ethol. 87: 79-89. 